\title{
The structure of the pelagic food web in relation to water column structure in the Skagerrak
}

\author{
Thomas Kiørboe ${ }^{1}$, Hanne Kaas ${ }^{2}$, Birger Kruse $^{2}$, Flemming Møhlenberg ${ }^{2}$, Peter \\ Tiselius $^{3}$, Gunni Ertebjerg ${ }^{2}$ \\ ${ }^{1}$ Danish Institute for Fisheries and Marine Research, Charlottenlund Castle, DK-2920 Charlottenlund, Denmark \\ ${ }^{2}$ National Environmental Research Institute, Jægersborg Allé 1B, DK-2920 Charlottenlund, Denmark \\ ${ }^{3}$ Kristineberg Marine Biological Laboratory, S-450 34 Fiskebäckskil, Sweden
}

\begin{abstract}
The distribution, composition and activity of phytoplankton, and accompanying changes in specific activities of bacterioplankton and copepods, were related to variations in the vertical structure of the water column along a transect through the Skagerrak in May 1987. The Skagerrak is characterized by a doming of the pycnocline, with a deep mixed layer along the periphery and a very shallow pycnocline in central parts. Average phytoplankton size increased with the depth of the upper mixed layer, and the central stratified area was characterized by small flagellates while large and chainforming diatoms dominated along the periphery. In situ fecundities of 2 copepod species (Temora longicornis and Acartia clausi) increased linearly with the concentration of phytoplankton (chl a) $>8 \mu \mathrm{m}$ and were, therefore, highest along the Skagerrak margin. Specific growth rates of bacterioplankton appeared to depend on particle surface area rather than particle volume or chl $a$, and showed a distributional pattern that was nearly the inverse of the distribution of copepod activity. That is, peak bacterial growth rates occurred in central, stratified parts and lower rates were found along the margin with a deep mixed layer. Thus a 'microbial loop' type of food web seemed to be evolving in the central, strongly stratified parts of the Skagerrak, while a shorter 'classical' type of food web appeared to dominate along the margin. The relation between food web structure and vertical mixing processes observed on oceanwide scales, e.g. between oligotrophic ocean gyres and the major upwelling systems, thus seems to recur on much smaller horizontal scales.
\end{abstract}

\section{INTRODUCTION}

The abundance, species- and size-distribution of phytoplankton in the sea depend to a large extent on physical processes. Thus, it is generally believed that small autotrophic flagellates and cyanobacteria dominate in oligotrophic, stratified water, whereas large species (e.g. diatoms) characterize turbulent, nutrientrich environments (e.g. Malone 1980, Legendre 1981, Harris et al. 1987). The seasonal and oceanwide variation in phytoplankton species composition fits into this generalization, but it appears that similar variation in floral composition may recur on much smaller temporal or horizontal scales, e.g. in association with windgenerated (e.g. Hitchcock et al. 1987, Tanaka et al. 1988) or upwelling-generated (e.g. Furyua \& Marumo 1983) vertical mixing events.

The fate of phytoplankton production in the pelagic food chain must depend strongly on the size of primary producers. Mesozooplankton, e.g. cope- pods, feed mainly on phytoplankton larger than 5 to $10 \mu \mathrm{m}$ (e.g. Frost 1972, Berggreen et al. 1988). Thus, large phytoplankters may be consumed by copepods or they may sediment to the bottom (e.g. Smetacek 1980) due to a high sinking rate. Small cyanobacteria and photosynthetic flagellates $(<10 \mu \mathrm{m})$, on the other hand, may be eaten by heterotrophic flagellates or protozooplankton, respectively. Part of the photosynthetically fixed carbon may leak from phytoplankton cells as dissolved organic matter (DOM) and be taken up by pelagic bacteria that in turn may be consumed by small heterotrophic flagellates. The fraction of autotrophically fixed carbon exudated as DOM seems to increase with decreasing environmental concentration of inorganic nutrients (e.g. Joiris et al. 1982). Furthermore, it has been suggested that exudation of DOM from phytoplankters is due to passive diffusion through the cell membrane (Bjørnsen 1988). One would, therefore, expect small cells to lose a greater proportion of the 
photosynthetically fixed carbon as DOM than large cells (see also Fogg 1986)

The hypothetical picture that emerges, therefore, is that a stratified, oligotrophic water column may give rise to dominance of small phytoplankters, relatively high DOM-production rates and a long 'microbial loop' (Azam et al. 1983) type of food chain. In contrast, a turbulent environment may give rise to growth of larger phytoplankters and to a shorter 'classical' type of grazing food web (phytoplankton-zooplanktonfish), where a larger proportion of the primary production is potentially channelled to higher trophic levels. Hydrodynamic processes may thus control the relative importance of these 2 'alternative' pathways for primary production. Such variation in the structure of the pelagic food web is thought to occur on seasonal and oceanwide scales (e.g. Cushing 1989), but may recur on much finer temporal and horizontal scales.

In the present study we have approached the above hypothesis by examining the structure of the pelagic food web in relation to horizontal variations in the vertical structure of the water column in the Skagerrak (Fig. 1). The Skagerrak is characterized by a domeshaped pycnocline (e.g. Pingree et al. 1982). In the central Skagerrak the upper mixed layer is only ca $10 \mathrm{~m}$ deep, whereas in the periphery it extends to $60 \mathrm{~m}$ or to the bottom. Thus, within short distances, there is a pronounced variation in the vertical structure of the water column.

Plankton distributions are determined both by water movements and by growth and mortality rates. Advection represents an inherent complication to the study of (in particular small-scale) horizontal and temporal variation in the structure of the pelagic food web and even in a stable environment the biomass of organisms may oscillate due to predator-prey interactions.
Therefore, the approach taken in this study was to look at mass-specific growth rates of selected groups of organisms rather than solely on their biomass distributions, and to relate specific growth rates to physical processes and relevant components of the biotic community. The specific aims of the present study were to investigate the distribution, composition and activity of phytoplankton in relation to variations in the vertical structure of the water column along a transect through the Skagerrak, and to study accompanying changes in the specific activities of mesozooplankton (copepods) and microorganisms (bacteria). These groups of organisms are here considered representative of the 'classical' food chain and the 'microbial loop', respectively.

\section{MATERIALS AND METHODS}

The survey was conducted during a cruise with RV 'Gunnar Thorson' between 18 and 21 May 1987. Observations were carried out at 12 stations along a transect from Hirtshals in Denmark to the island of Torungen in Norway (Fig. 1). One station (Stn 4) was revisited on 22 May. All stations were occupied during daytime. Profiles of temperature and salinity were obtained by a Guildline CTD and in situ fluorescence and turbidity by a fluorometer and C-meter ( $Q$ Instruments; Hundahl \& Holck 1980), respectively. Vertical irradiance attenuation was calculated from the turbidity measurements. Surface irradiance was recorded by a Li-cor cosine Quantum sensor $(400$ to $700 \mathrm{~nm}$ ). Water samples for nutrients $\left(\mathrm{PO}_{4}^{3-}, \mathrm{NO}_{3}^{-}, \mathrm{NH}_{4}^{+}\right)$were collected at 4 to 13 depths with Nansen bottles and immediately analysed on board with an autoanalyser $\left(\mathrm{PO}_{4}^{3-}\right.$ and $\mathrm{NO}_{3}^{-}$; Olsen \& Lundgren 1984) or manually

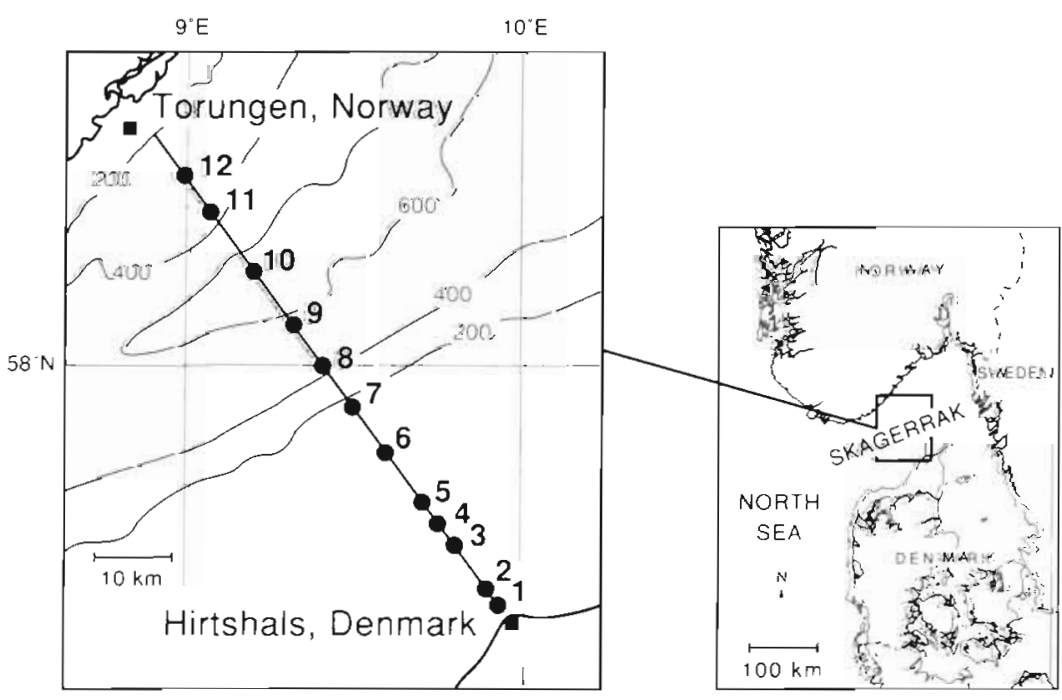

Fig. 1 The Skagerrak and position of sampling stations along the Hirtshals-Torungen transect 
$\left(\mathrm{NH}_{4}^{+}\right.$; Grasshoff 1976). Samples for determination of chl a were collected with 5 or 301 Niskin bottles at 4 or 5 depths in the upper $30 \mathrm{~m}$ and analysed spectrophotometrically after filtration (Whatman GF/F) and overnight extraction in $96 \%$ ethanol (Jespersen \& Christoffersen 1987). At selected depths chlorophyll extractions of $>8 u \mathrm{~m}$ particles (Nuclepore filter) were also made. Samples for measurements of bacterial biomass and production, carbon $\left({ }^{14} \mathrm{C}\right)$ and nitrogen $\left({ }^{15} \mathrm{~N}\right)$ incorporation rates, particle size distribution (Coulter Counter TAII, $140 \mu \mathrm{m}$ orifice tube), particulate carbon and nitrogen (filtered onto precombusted GF/F filters and analysed on a Perkin Elmer CHN-elemental Analyzer 240C) and species-and size-composition of phytoplankton were taken from the same water bottles as the chlorophyll samples. Phytoplankton samples were preserved in Lugol's solution, sedimented in $10 \mathrm{ml}$ chambers and counted under the inverted microscope. Only cells larger than $3 \mu \mathrm{m}$ were considered and no attempt was made to distinguish autotrophic and heterotrophic flagellates. Phytoplankton carbon was estimated using the stereometric shapes and plasma volume/carbon conversion procedure described by the Baltic Marine Environment Protection Commission - Helsinki Commission (1988). ${ }^{15} \mathrm{~N}$ uptake rates and floral composition were only undertaken at selected depths.

Primary production. Productivity samples $(3$ to 5 depths) were transferred to $25 \mathrm{ml}$ acid-washed Pyrex. bottles, and ca $2 \mu \mathrm{Ci}$ of $\mathrm{NaH}^{14} \mathrm{CO}_{3}$ was added to each bottle. Bottles were subsequently attached to a rotating wheel and incubated for $2 \mathrm{~h}$ at ambient seawater temperature $\pm 1{ }^{\circ} \mathrm{C}$ and at 8 different photon flux densities from 0 to $760 \mu \mathrm{E} \mathrm{m} \mathrm{m}^{-2} \mathrm{~s}^{-1}$. Light in the incubator was provided by Philips fluorescence tubes, TL 20w/33. Subsequently the samples were filtered through $0.45 \mu \mathrm{m}$ Sartorius membrane filters, the filters acid-fumed to remove unfixed ${ }^{14} \mathrm{CO}_{2}$ and scintillation cocktail added (Filter-Count, Packard). After the cruise radioactivity and quenching associated with the samples were determined. In situ productivity at depths was estimated from P vs I curves, light attenuation in the water column and surface irradiance (Gar. gas et al. 1976).

Uptake rates of $\mathrm{NH}_{4}^{+}$and $\mathrm{NO}_{3}^{-}$. In an attempt to estimate the relative contributions to primary production of 'new' nutrients $\left(\mathrm{NO}_{3}^{-}\right)$, transported to the photic zone from below the pycnocline, and nutrients regenerated $\left(\mathrm{NH}_{4}^{+}\right)$within the photic layer (Dugdale \& Goering 1967), estimates of ${ }^{15} \mathrm{NH}_{4}^{+}$and ${ }^{15} \mathrm{NO}_{3}^{-}$uptake rates were made at 4 stations (Stns 4, 9, 10 and 12) along the transect at the depth of maximum in situ fluorescence.

The uptake experiments were initiated after addition of trace $\left(0.04 \mu \mathrm{mol}{ }^{15} \mathrm{NH}_{4}^{+}\right]^{-1}, 2$ to $16 \%$ of ambient $\mathrm{NH}_{4}^{+}$ or $0.2 \mu \mathrm{mol}^{15} \mathrm{NO}_{3}^{-} \mathrm{l}^{-1}, 3$ to $31 \%$ of ambient $\mathrm{NO}_{3}^{-}$) and saturating $\left(0.8 \mu \mathrm{mol}{ }^{15} \mathrm{NH}_{4}^{+} \mathrm{l}^{-1}\right.$ or $\left.4 \mu \mathrm{mol}{ }^{15} \mathrm{NO}_{3}^{-} \mathrm{l}^{-1}\right)$ concentrations of labelled nitrogen. At 2 stations additional incubations were carried out using intermediate additions of $0.2 \mu \mathrm{mol}^{15} \mathrm{NH}_{4}^{+} \mathrm{l}^{-1}$ and $1 \mu \mathrm{mol}{ }^{15} \mathrm{NO}_{3}^{-} \mathrm{l}^{-1}$, respectively.

Samples were incubated for 2.5 to $3 \mathrm{~h}$ (in one instance $6 \mathrm{~h}$ ) in $2.5 \mathrm{l}$ polycarbonate bottles placed in deck incubators with flowing seawater. Light was screened to simulate the level at the sampling depth (usually about $10 \%$ of surface irradiance). Actual light levels in the incubators were monitored using a Li-cor quantameter. During incubation, 4 to 5 samples $(0.5 \mathrm{l})$ were filtered on to $25 \mathrm{~mm}$ precombusted GF/F filters to follow the time course of ${ }^{15} \mathrm{~N}$ uptake. The filters were rinsed with filtered seawater and dried in a dessicator under vacuum.

Photosynthetic carbon fixation was assessed simultaneously with the N-uptake experiments in unenriched samples. In the deck incubator, $25 \mathrm{ml}$ water with $2 \mu \mathrm{Ci} \mathrm{H}^{14} \mathrm{CO}_{3}$ was incubated. After ca $2 \mathrm{~h}$ algal cells were collected by gentle filtration onto $0.45 \mu \mathrm{m}$ Millipore filters and processed as described above.

Preparation of samples for ${ }^{15} \mathrm{~N} /{ }^{14} \mathrm{~N}$ assessment was carried out according to Kristiansen \& Paasche (1982). After a Dumas reaction, incorporation of ${ }^{15} \mathrm{~N}$ was analysed by microwave emission spectroscopy according to Saby Johansen (1984).

For each incubation the enrichment of ${ }^{15} \mathrm{~N}$ in particulate material was plotted against incubation time. In most cases the correlation coefficients for the linear regressions were above 0.95 (and often above 0.99), however, at very low nitrate enrichments correlation coefficients as low as 0.87 were obtained. The relatively short incubation periods used and the linear ammonium uptake suggest that isotope dilution due to remineralization of ammonium was insignificant. Therefore, we did not attempt to correct for isotope dilution.

The specific uptake rate was calculated as

$$
V=\frac{{ }^{15} N(s s)}{{ }^{15} \mathrm{~N} \text { excess in water }} h^{-1}
$$

where the ${ }^{15} \mathrm{~N}(\mathrm{ss})=$ slope of the linear regression of ${ }^{15} \mathrm{~N} \%$ in particulate material against time; and ${ }^{15} \mathrm{~N}$ excess $=$ the excess ${ }^{15} \mathrm{~N} \%$ in incubation water at the start of incubation. The absolute rate of $N$ uptake was calculated as $\mathrm{V} \times \mathrm{PN}$, where $\mathrm{PN}=$ particulate nitrogen.

At 2 stations (Stns 4 and 9) the $\mathrm{N}$ uptake was stimulated by the $\mathrm{NH}_{4}^{+}$additions. In these instances, in situ uptake rates were calculated according to the Michaelis-Menten equation. For all other incubations, which showed no influence of different nutrient addition, the uptake rates were averaged.

Bacterial biomass and production. Water samples of 
$20 \mathrm{ml}$ were fixed with borate-buffered formalin to $2 \%$ final concentration and stored in furnaced glass vials. Determination of bacterial abundance essentially followed Hobbie et al. (1977), only differing by staining with diamidinophenylindole (DAPI) instead of acridin orange. At least 50 fields and a total of 500 cells were examined under UV-light in a Leitz-Orthoplan epifluorescence microscope. Bacterial cell size distribution was estimated from measurements of length and width (to within $0.45 \mu \mathrm{m}$ ) of at least 60 cells, and mean cell volume determined according to Bjørnsen (1986). To achieve biomass values a conversion factor of $0.12 \times$ $10^{-6} \mu \mathrm{g} \mathrm{C} \mu \mathrm{m}^{-3}$ (Watson et al. 1977) was used.

Bacterial net production was measured by a tritiated thymidine incorporation (TTI) method (Fuhrman \& Azam 1980). Water samples of $20 \mathrm{ml}$ were incubated with $10 \mathrm{nM}{ }^{3} \mathrm{H}$-methyl thymidine (specific activity: 4.44 $10^{16} \mathrm{dpm} \mathrm{mol}^{-1}$ ) for $30 \mathrm{~min}$ at in situ temperature. Incubation was stopped by adding formalin ( $2 \%$ final conc.) and $15 \mathrm{ml}$ samples were filtered through $0.2 \mu \mathrm{m}$ membrane filters (Sartorius). The filters were rinsed 10 times with $1 \mathrm{ml}$ ice-cold $5 \%$ trichloroacetic acid (TCA) and then solubilized in vials with $500 \mu \mathrm{l}$ ethylacetate added. Scintillation cocktail $(10 \mathrm{ml})$ was added before liquid scintillation counting. Bacterial net production was calculated assuming a conversion factor of $1.1 \times$ $10^{18}$ cells mol ${ }^{-1}$ (Rieman et al. 1987), and biovolumes and carbon content as above. Bacterial generation time was calculated by dividing the bacterial net production by the bacterial biomass

Copepod egg production. Copepod egg production. rate was used as a measure of female specific 'growth' rate. This measure appears also to be representative for juvenile specific growth rate (Berggreen et al. 1988). Rates of in situ egg production of the copepods Temora longicornis and Acartia clausi were determined as described in Kiørboe et al. (1985). Copepods were sampled by towing a 200 um WP-2 net (Tranter 1968) in the upper mixed layer. On deck the contents of the cod-end was immediately diluted into ca $15 \mathrm{l}$ water from the sampling depth. Within 1 to $2 \mathrm{~h}$ after capture, fertilized females were sorted out and incubated in $600 \mathrm{ml}$ screw-cap bottles in natural water at in situ temperature. Between 2 and 5 individuals were incubated in each of 4 to 6 replicate bottles for each species. After ca $24 \mathrm{~h}$ spawned eggs were counted. Egg-cannibalism was corrected for as in Kiørboe et al. (1985). Of each species 10 to 20 individuals were measured for cephalothoracic length at each station. Fecundity was expressed as number of eggs produced female ${ }^{-1}$ day $^{-1}$ In the case of $T$. longicornis female sizes differed significantly between stations (1.01 to $1.23 \mathrm{~mm}$ cephalothorax length, L), and egg production in this species was expressed for a standard $(1.00 \mathrm{~mm})$ individual by dividing by $\mathrm{L}^{3}$

\section{RESULTS}

\section{Hydrography and nutrient distribution}

Isopleth diagrams of salinity, temperature and inorganic nutrients along the transect are shown in Fig. 2. Variations in density (sigma-t) generally followed salinity variations and sigma-t has been included in subsequent figures to guide interpretation (Figs. 3,6 and 9).

A doming of the pycnocline and nutriclines $\left(\mathrm{NO}_{3}^{-}\right.$, $\mathrm{PO}_{4}^{3-}$ ) across the Skagerrak is evident. At the 2 southernmost, shallow stations, the water column was vertically isohaline and isothermal and, hence, mixed to the bottom, whereas there was a strong pycnocline at 8 to $10 \mathrm{~m}$ depth in the central Skagerrak (Stns 4 to 7 ). Between Stns 9 and 11, high-salinity $(>32 \%)$, cold $\left(<7^{\circ} \mathrm{C}\right)$ water occurred at the surface, the surface mixed layer deepened ( 15 to $20 \mathrm{~m}$ ) and the vertical stability decreased. At Stn 12 (21 May) low-salinity, warmer water again occurred at the surface. This water is the Norwegian Coastal Current caused by outflow from the Baltic and several large rivers that empty into the Oslo Fjord. It was promoted by the onset of northeastrely winds $\left(>10 \mathrm{~m} \mathrm{~s}^{-1}\right)$ from 20 May.

In addition to these gross features, temperature and salinity anomalies are evident at several stations at 30 to $60 \mathrm{~m}$ depth, in particular at Stns 7 and 11. These lenses of high-salinity/high-temperature water may be interpreted as water horizontally advected from elsewhere, presumably from the surface of the North Sea.

The concentration of phosphate was below the limit for chemical detection or very low $(<0.06 \mu \mathrm{M})$ in the upper mixed layer in the entire area. In contrast, significant concentrations of $\mathrm{NH}_{4}^{+}(>0.2 \mu \mathrm{M})$ and $\mathrm{NO}_{3}^{-}$ $(>0.2 \mu \mathrm{M})$ occurred in the upper mixed layer at all stations, the latter nutrient in particular at the northernmost stations. The high concentration of inorganic nitrogen in surface waters of these stations was presumably caused by wind-generated entrainment or mixing of nutrient-rich water from below the pycnocline due to the relatively low vertical stability here, the steep nutricline and the fairly strong winds prevailing during this cruise $\left(10\right.$ to $15 \mathrm{~m} \mathrm{~s}^{-1}$, up to $\left.20 \mathrm{~m} \mathrm{~s}^{-1}\right)$. Inorganic phosphorus would be transported along with nitrogen due to entrainment, but presumably because the molar ratios of inorganic nitrogen to phosphorus exceeded the Redfield ratio of 16 below the pycnocline of Stns 9 to 11, elevated concentrations of phosphate were not particularly evident in the surface waters here.

One conspicious feature of the ammonium isopleth diagram is the high concentrations of $\mathrm{NH}_{4}^{+}$occurring below the pycnocline at several stations, suggesting high heterotrophic activity here. At Stn 7 this feature extended to more than $75 \mathrm{~m}$ depth, and to some extent coincided with the salinity-temperature anomaly. 

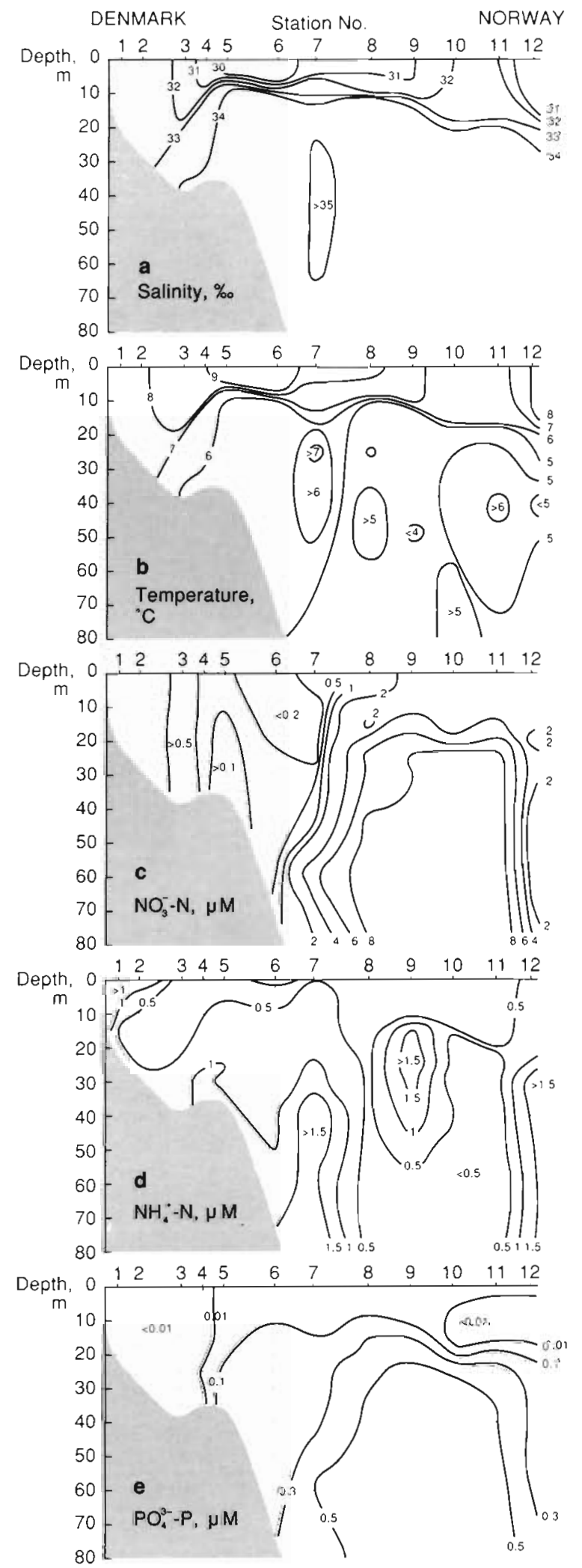

Fig. 2. Vertical distributions of (a) salinity, (b) temperature, (c) nitrate, (d) ammonium, and (e) phosphate along the transect. Dots show positions of water samples

\section{Phyloplankton and primary production}

The distribution of extracted chlorophyll a, in situ fluorescence and concentration of suspended particles (Fig. 3b, c, d) all suggest elevated phytoplankton biomass in surface waters centered around Stn 10, concurrent with the decreased vertical stability An additional bloom is apparent below the $33 \%$ isohaline at Stns 3 to 5 (in particular evident from the fluorescence plot), with highest fluorescence values immediately above the bottom. At Stn 3, $2 \%$ of surface irradiance extended to $30 \mathrm{~m}$ depth. Estimates of daily productivity (Fig. 3e) of course decreased with depth, but otherwise largely followed variations in extracted chlorophyll a.

Representative particle size-distributions (Coulter Counter) for southern mixed (Stn 2), central stratified
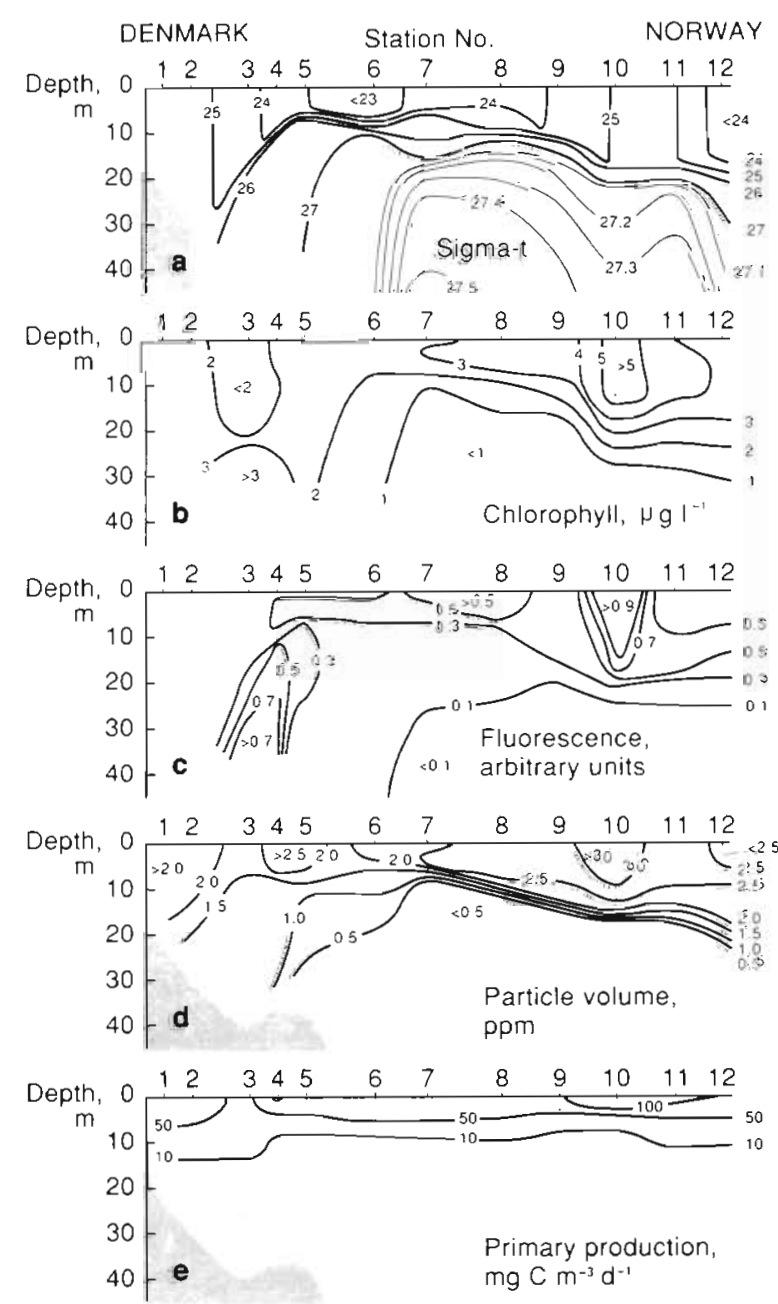

Fig, 3. Vertical distributions of (a) water density, (b) chlorophyll $a$, (c) in situ fluorescence, (d) concentration of suspended particles and (e) primary production. Dots show sampling depths. Note that isolines are separated by 0.1 sigma-t units for sigma-t $>27$ (thin lines) and by 1.0 unit for sigma- $t<27$ (thick lines) 
(Stn 5) and northern 'entrainment' (Stn 11) stations are shown in Fig. 4. Large particles (ca $40 \mu \mathrm{m}$ equivalent spherical diameter, ESD) dominated in southern mixed water, whereas small particles (ca $7 \mu \mathrm{m}$ ESD) dominated at central, stratified stations. At the northern stations 2 biomass peaks (ca 7 and 40 um ESD) were evident. The isopleth diagram of the ratio of large to small particles complements this picture and in addition suggests that average particle size increased with depth (Fig. 9b). With the exception of Stn 12 there
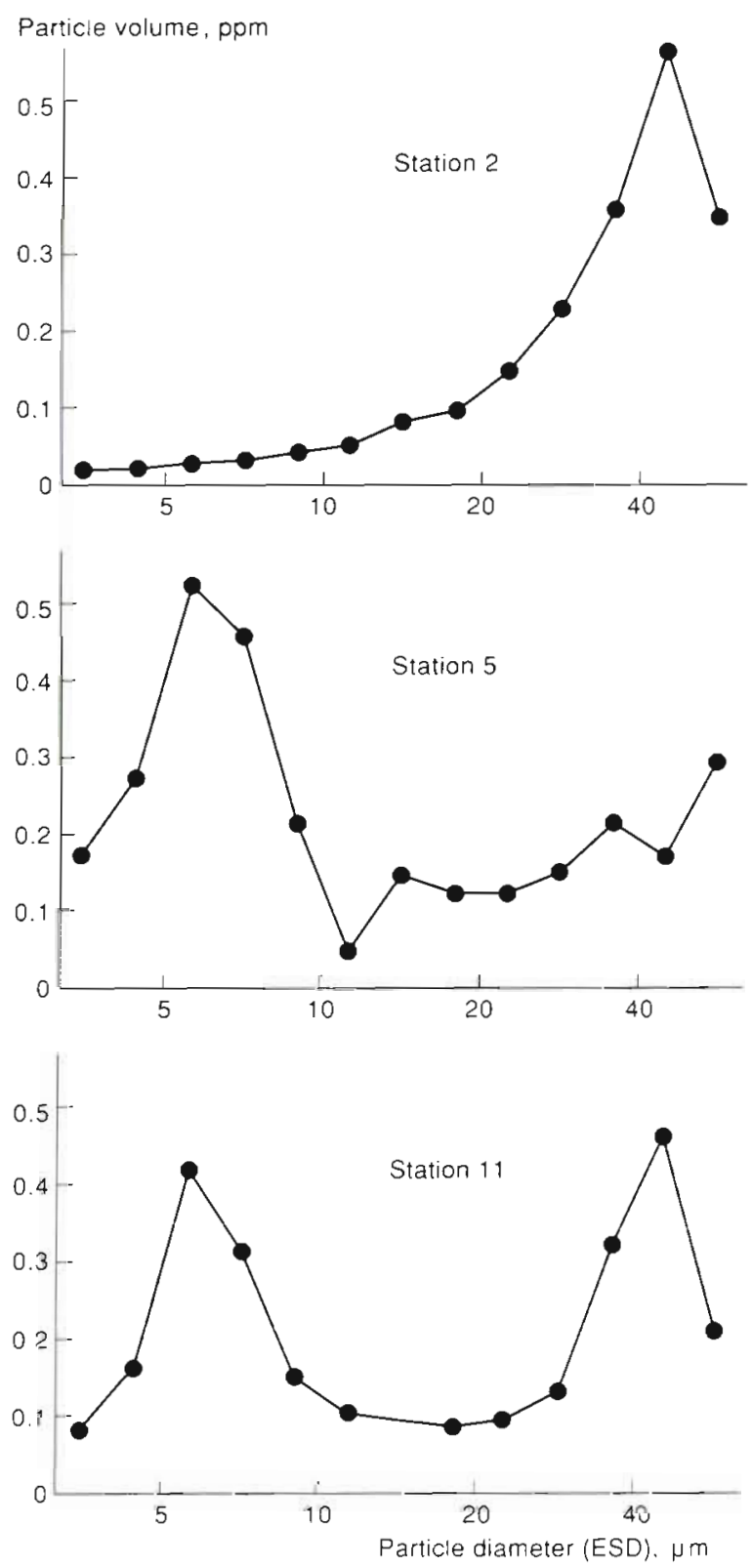

Fig. 4. Size-distribution of suspended particles as reveaied by the Coulter Counter in surface waters of Stn 2 (mixed), 5 (shallow mixed layer) and 11 (deep mixed layer). Samples were taken at $9.5,4$ and $12 \mathrm{~m}$ depth, respectively appeared to be a positive relation between particle size and the depth of the upper mixed layer (Fig. 5)

Comparisons of Coulter Counter analyses to microscopic analyses of water samples and determinations of fractionated chlorophyll a confirm that Coulter Counter analyses largely reflect the size-distribution of phytoplankton and confirm the general pattern of variation in phytoplankton size along the transect (Table 1). Microscopic and Coulter Counter analyses yielded largely identical ratios of large to small algae along the transect. Fractionated chlorophyll yielded somewhat lower estimates of this ratio in southern mixed water and somewhat higher estimates at northern stations, but the general trend is the same.

Microscopic analyses further revealed that the plankton-flora was dominated by various Rhizosolenia species (diatoms) in southern, mixed water; by small, largely unidentified nanoflagellates at central stratified stations; and by chainforming Chaetoceros species (diatoms) at the northern 'entrainment' stations

The intention to utilize ${ }^{15} \mathrm{NO}_{3}^{-}$and ${ }^{15} \mathrm{NH}_{4}^{+}$uptake rates to distinguish 'new' and 'regenerated' production was only partly successful. This was due both to the high concentrations of $\mathrm{NH}_{4}^{+}$in the photic layer and the inhibitory effect of $\mathrm{NH}_{4}^{+}$on $\mathrm{NO}_{3}^{-}$-uptake (e.g. Paasche 1988), and to the high concentration of $\mathrm{NH}_{4}^{+}$below the pycnocline. Hence, $\mathrm{NH}_{4}^{+}$is not necessarily regenerated within the photic zone, but may be transported from below the pycnocline. This may be exemplified by the repeated observations at $\operatorname{Stn} 4$ that was revisited on 22

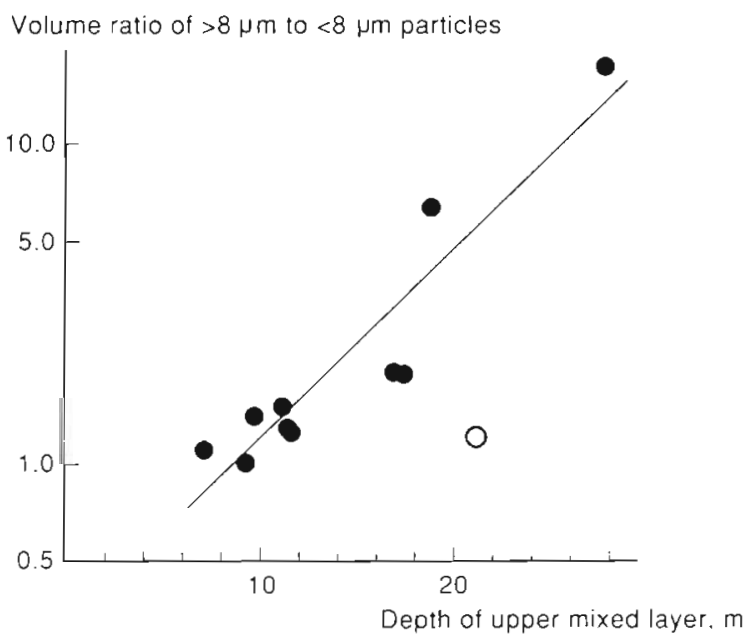

Fig. 5. Relationship between particle size (Coulter Counter) and depth of upper mixed layer, represented by depth of the 26 sigma-t isopycnal (or water depth at Stn 2). Particle size data from Table 1. (O) Observation from Stn 12 that was excluded from the regression: $\mathrm{Y}=-1.15 \times 0.13 \mathrm{X}, \mathrm{r}=0.92$ $(p<0.05)$. Using fractionated chlorophyll or microscopic cell counts (Table 2) to calculate the dependent varable also yielded significant relations 
Table 1. Ratio of 'net' - to 'nano'-plankton ( $>8 \mu \mathrm{m}$ and $<8 \mu \mathrm{m}$, respectively) biomass measured by size-fractionated chlorophyll $a$, Coulter Counter (volume) or visual counts (plasma volume) along the Hirtshals-Torungen transect. All water samples were taken in the upper mixed layer

\begin{tabular}{|c|c|c|c|c|c|c|c|c|c|c|c|}
\hline \multirow[t]{2}{*}{ Measure } & \multicolumn{11}{|c|}{ Stn } \\
\hline & 2 & 3 & 4 & 5 & 6 & 7 & 8 & 9 & 10 & 11 & 12 \\
\hline Sampling depth $(\mathrm{m})$ & 9.5 & 18 & 5 & 4 & 2 & 3 & 3.5 & 5 & 8 & 12 & 6 \\
\hline Size-fractionated chlorophyll a & 3.7 & 1.7 & 2.2 & 2.1 & 2.2 & 2.4 & 2.0 & 2.1 & 4.3 & 4.7 & 2.8 \\
\hline Coulter Counter & 17.8 & 6.3 & 1.3 & 1.1 & 1.0 & 1.3 & 1.4 & 1.5 & 1.9 & 1.9 & 1.2 \\
\hline Microscopic counts & 12.2 & 7.8 & 1.0 & 0.8 & 1.2 & 0.7 & 1.3 & 0.8 & 0.6 & 2.1 & 1.5 \\
\hline
\end{tabular}

May subsequent to the transect study and $4 \mathrm{~d}$ after the first visit. At this occasion the water column was mixed to the bottom, the ammonium concentration had increased by a factor of 8 and was now the dominating nitrogen source (Table 2). Nevertheless the data suggest that $\mathrm{NO}_{3}^{-}$is a more important nitrogen source at Stns 9 and 10 (56 and $39 \%$ of total N-uptake) than at stratified $\operatorname{Stn} 4$ (31\% of total uptake). This is consistent with the idea of enhanced vertical nutrient flux at Stns 9 and 10. The relative importance of $\mathrm{NO}_{3}^{-}$at Stn 10 becomes more evident if $\mathrm{NO}_{3}^{-}$-uptake is assumed to depend on light intensity and $\mathrm{NH}_{4}^{+}$-uptake to be lightindependent, since the irradiance in the Stn 10 incubation was much less than at the other stations. Likewise, molar uptake ratios of $\mathrm{C} /\left(\mathrm{NO}_{3}^{-}+\mathrm{NH}_{4}^{+}\right)$(between 8 and 15; Table 2) may approach the Redfield ratio if we assume dark-uptake of $\mathrm{NH}_{4}^{+}$at daytime rates.

Addition of ${ }^{15} \mathrm{~N}$ labelled nutrients in saturating concentrations suggested enhanced uptake rate by surplus addition of ammonium at Stns 4 (2.5-fold) and 9 (1.5fold), but no effects at Stns 10 and 12 . In no case did $\mathrm{NO}_{3}^{-}$-addition affect uptake rates.

\section{Bacterial biomass and net production}

Bacterial biomass varied by more than an order of magnitude in surface waters along the transect. It was highest in shelf surface waters, up to $125 \mu \mathrm{g} \mathrm{Cl}^{-1}$, and decreased towards the central and northern part of the Skagerrak (Fig. 6c). Additional minor peaks in biomass were evident at Stns 9 and 10 and at Stn 12 near the Norwegian coast. Bacterial abundance showed a similar distributional pattern with peak concentrations of $4.5 \times 10^{6}$ cells ml-1 (Fig. 6b). Estimated biovolumes of bacteria were generally high, averaging $0.20 \mu \mathrm{m}^{3} \mathrm{cell}^{-1}$ and varying from 0.1 to 0.3 between stations. These volumes are up to 3 or 4 times those normally reported and may have been overestimated. Assuming a carbon-to-chlorophyll conversion factor of 25 (19 to $32, \bar{x}=$ 25, calculated from determinations of algal carbon and chlorophyll a; cf. Table 2), bacterial biomass exceeded phytoplankton biomass at the southernmost station, and was of a similar order of magnitude at central stations, while phytoplankton biomass considerably exceeded bacterial biomass at the 'entrainment' stations (compare Figs. 3 and 6).

Bacterial net production showed a somewhat different picture than biomass, with peak rates in surface waters of the strongly stratified, central Stns 5 and 6 , additional peaks at the southern-and northernmost coastal stations and minimum rates at stations with a deeper mixed layer (i.e. Stns 2 to 4,10 and 11) (Fig. 6d). Estimated daily bacterial net production, like biomass, was of a similar magnitude to primary production (both integrated to $30 \mathrm{~m}$ ) at southern and central stations,

Table 2. Uptake rates of nitrate and ammonium measured by $15-\mathrm{N}$ technique at 4 stations along the Hirtshals-Torungen transect. Sampling depths and concentrations of nutrients and phytoplankton (chlorophyll a and algal carbon) in incubated samples as well as incubation light intensity (PAR) have also been shown. Stn 4 was revisited (4-II) after sampling of the main transect

\begin{tabular}{|c|c|c|c|c|c|c|c|c|c|c|c|}
\hline \multirow[t]{2}{*}{ Stn } & \multirow[t]{2}{*}{$\begin{array}{l}\text { Depth } \\
(\mathrm{m})\end{array}$} & \multirow{2}{*}{$\begin{array}{c}\overline{\mathrm{PAR}} \\
\left(\mu \mathrm{Em} \mathrm{m}^{-2}\right. \\
\left.\mathrm{s}^{-1}\right)\end{array}$} & \multirow[t]{2}{*}{$\begin{array}{c}\text { Chla } \\
\left(\mu \mathrm{gl}^{-1}\right)\end{array}$} & \multirow[t]{2}{*}{$\begin{array}{l}\text { Algal-C } \\
\left(\mu g l^{-1}\right)\end{array}$} & \multirow[t]{2}{*}{$\mathrm{NH}_{4}^{+}$} & \multirow{2}{*}{$\mathrm{NO}_{3}^{-}$} & \multicolumn{3}{|c|}{ Uptake $\left(\mu \mathrm{mol} 1^{-1} \mathrm{~h}^{-1}\right)$} & \multicolumn{2}{|c|}{$\begin{array}{l}\text { Specific uptake } \\
\left(\mu \mathrm{mol} \mathrm{mgC}^{-1} \mathrm{~h}^{-1}\right)\end{array}$} \\
\hline & & & & & & & $\mathrm{NH}_{4}^{+}$ & $\mathrm{NO}_{3}^{-}$ & $\mathrm{CO}_{2}$ & $\begin{array}{c}\left(\mathrm{NH}_{4}^{+}+\right. \\
\left.\mathrm{NO}_{3}^{-}\right)\end{array}$ & $\mathrm{CO}_{2}$ \\
\hline 4 & 5 & 80 & 2.6 & 70 & 0.2 & 0.4 & 0.018 & 0.008 & 0.342 & 0.37 & 4.89 \\
\hline 4 -II & 6 & 135 & 1.5 & 31 & 1.6 & 0.6 & 0.016 & 0.001 & 0.267 & 0.55 & 8.61 \\
\hline 9 & 5 & 83 & 3.1 & 91 & 0.4 & 3.3 & 0.026 & 0.033 & 0.750 & 0.65 & 8.24 \\
\hline 10 & 12 & 44 & 5.9 & 113 & 0.5 & 3.0 & 0.037 & 0.024 & 0.680 & 0.54 & 6.10 \\
\hline 12 & 6 & 80 & 3.9 & 132 & 0.7 & 3.6 & 0.024 & 0.020 & 0.367 & 0.33 & 2.78 \\
\hline
\end{tabular}



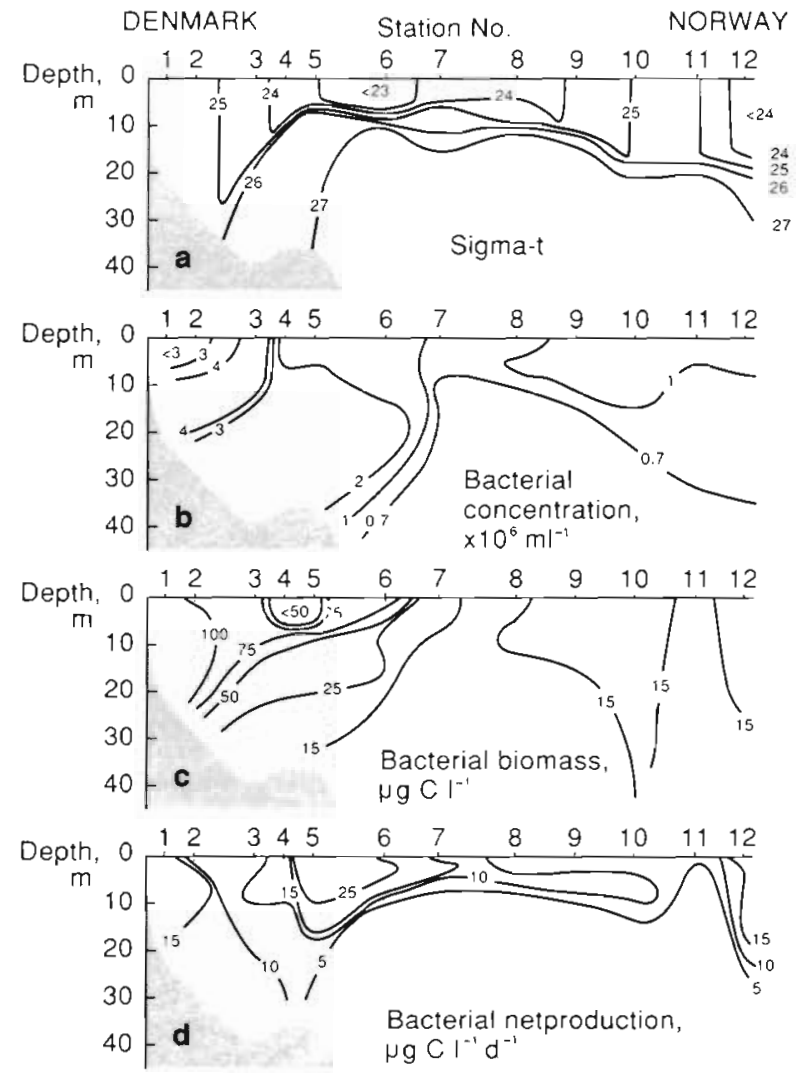

\begin{tabular}{cccccccccccc} 
Station No & 2 & 3 & 4 & 5 & 6 & 7 & 8 & 9 & 10 & 11 & 12 \\
\hline \begin{tabular}{c} 
Bacterial production \\
\hline Primary production
\end{tabular} & 0.8 & 0.9 & 0.7 & 1.3 & 0.6 & - & 0.3 & 0.3 & 0.4 & 0.1 & 1.1
\end{tabular}

Fig. 6. Vertical distributions of (a) water density, (b) bacterial concentration, (c) biomass and (d) net production along the transect. Lower panel shows the ratio of bacterial net production $\left(\mathrm{d}^{-1}\right)$ to primary production $\left(\mathrm{d}^{-1}\right)$, both integrated to $30 \mathrm{~m}$. Dots show sampling depths whereas it generally equalled less than $50 \%$ of primary production at Stns 8 to 11 (Fig. 6). Bacterial net production did not show significant relations to either the volume of suspended particles, concentration of chlorophyll $a$ or to primary production (Table 3 ).

The patches of elevated ammonium concentration below the pycnocline at several stations (Fig. 2) did not coincide with particularly high bacterial activity (Fig. 6). Therefore, either these high concentrations of ammonium were not due to bacterial activity, or the turnover rate of ammonium was very low at these positions.

\section{Specific growth rates of bacteria and copepods}

Bacterioplankton specific growth rate was proportional to the surface area of suspended particles in the upper mixed layer (Fig. 7; Table 3). Particle surface area was calculated from Coulter Counter analysis, assuming all particles to be spherical. Bacterial generation time, rather than specific growth rate, was used in this presentation (Fig. 7), simply because this transformation homogenizes the variance around the regression line. Bacterial generation time (and growth rate) also correlated significantly to volume of suspended particles and concentration of chlorophyll $a_{1}$ in both cases, however, with considerably lower coefficients of determination (Table 3). The growth rate of bacteria at Stn 12 near the Norwegian coast was higher than expected from the general relationships (e.g. Fig. 7) Particle size at this station also deviated from the general pattern (Fig. 5)

Specific fecundities of the copepods Temora longicornis and Acartia clausi were significantly intercorrelated $\left(\mathrm{r}^{2}=0.65\right)$ and in addition increased linearly

Table 3. Relationships between bacterial generation time, specific growth rate or net production (dependent variables) as functions of particle surface area, particle volume, chlorophyll a or primary production (independent variables) analysed by various models. $R^{2}$ coefficient of determination; $n$ : number of observations; p: probability level ( $t$-test); ns: $=$ not significant $(p>5 \%)$. Only observations from the upper mixed layer included. Observations from Stn 12 excluded

\begin{tabular}{|c|c|c|c|c|c|}
\hline $\begin{array}{l}\text { Dependent } \\
\text { variable }\end{array}$ & $\begin{array}{l}\text { Independent } \\
\text { variable }\end{array}$ & Model & $\mathrm{R}^{2}$ & $\mathrm{n}$ & $\mathrm{p}$ \\
\hline Generation time & $\begin{array}{l}\text { Surface area } \\
\text { Particle volume } \\
\text { Chl a }\end{array}$ & $Y=a X^{b}$ & $\begin{array}{l}0.90 \\
0.56 \\
0.41\end{array}$ & $\begin{array}{l}28 \\
28 \\
28\end{array}$ & $\begin{array}{l}<0.1 \% \\
<0.1 \% \\
<0.1 \%\end{array}$ \\
\hline Specific growth rate & $\begin{array}{l}\text { Surface area } \\
\text { Particle volume } \\
\text { Chl a }\end{array}$ & $Y=a+b X$ & $\begin{array}{l}0.58 \\
0.42 \\
0.16\end{array}$ & $\begin{array}{l}28 \\
28 \\
28\end{array}$ & $\begin{array}{l}<0.1 \% \\
<0.1 \% \\
<5 \%\end{array}$ \\
\hline Net production & $\begin{array}{l}\text { Surface area } \\
\text { Particle volume } \\
\text { ChI a }\end{array}$ & $Y=a+b X$ & $\begin{array}{l}0.014 \\
0.002 \\
0.078\end{array}$ & $\begin{array}{l}28 \\
28 \\
28\end{array}$ & $\begin{array}{l}\text { ns } \\
\text { ns } \\
\text { ns }\end{array}$ \\
\hline Net production $(0-30 \mathrm{~m})$ & $\begin{array}{l}\text { Primary production } \\
(0-30 \mathrm{~m})\end{array}$ & $Y=a+b X$ & 0.13 & 9 & ns \\
\hline
\end{tabular}




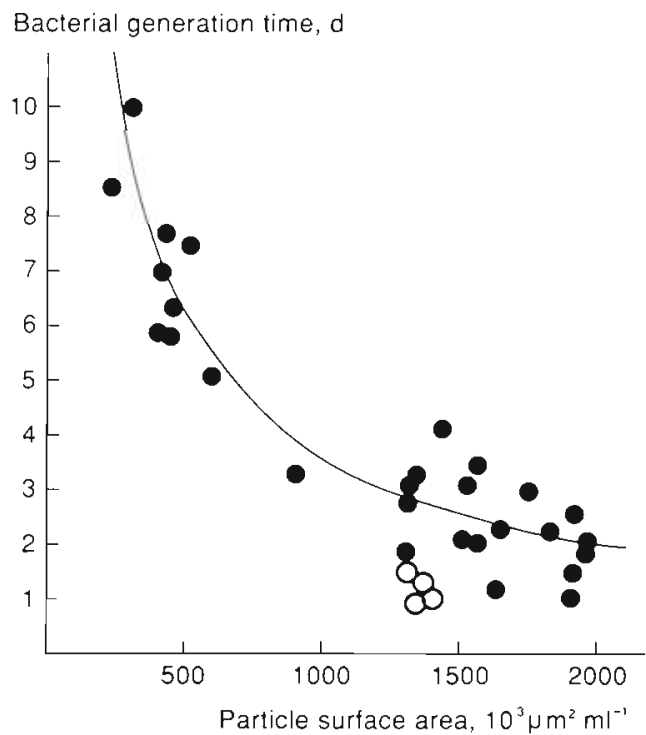

Fig. 7 Pelagic bacteria. Generation time as a function of the surface area of suspended particles $(2.5$ to $60 \mu \mathrm{m})$. (0) Observations at $\operatorname{Stn} 12$ that were excluded from the regression $Y=$ $1101 \mathrm{X}^{-0.82}\left(\mathrm{R}^{2}=0.90\right)$

with the concentration of chlorophyll a $>8 \mu \mathrm{m}$ (Fig. 8). However, apparently this relationship differed between 'shelf' (i.e. Stns 2 to 4 ) and other stations. The most likely explanation for this is that the phytoplankton species composition differed between stations (diatoms were mainly Rhizosolenia spp. at shelf stations and Chaetoceros spp. at other stations), and that edible phytoplankton were retained less efficiently by the $8 \mu \mathrm{m}$ filter at shelf stations due to the different shapes (cf. also Table 1).

\section{Structure of the pelagic food web}

While Figs. 3 and 6 have characterized components of the pelagic food web in terms of biomasses and absolute production rates, variations in mass-specific, instantaneous growth rates along the transect have been shown in Fig. 9 together with the ratio of large to small suspended particles. Assimilation number for primary production (light-saturated ${ }^{14} \mathrm{C}$ incorporation rate per unit chlorophyll a biomass) has been used as an index of (potential) phytoplankton growth rate in Fig. 9. The high growth rate of phytoplankton around Stn 9, as suggested by assimilation number, is further substantiated by high specific N-uptake rates at Stns 9 and 10 (Table 2). Peak fecundities of copepods occurred at the periphery of the Skagerrak, concurrent with a deep mixed layer, dominance of large phytoplankton with $\mathrm{NO}_{3}^{-}$as an important nitrogen source and, to some extent, high phytoplankton assimilation numbers. The
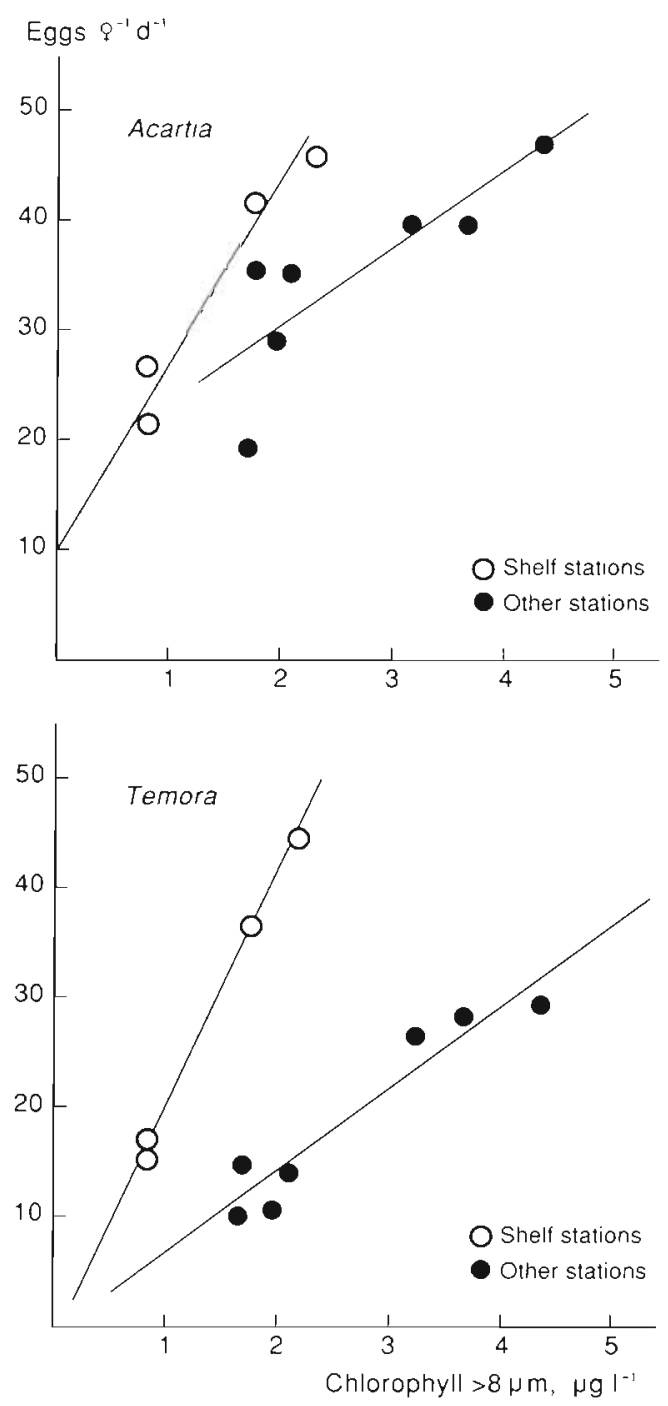

Fig. 8. Temora longicomis and Acartia clausi. Egg-production rates as a function of the concentration of chlorophyll $a$ within particles retained on a $8 \mu \mathrm{m}$ filter. Separate relations have been given for 'shelf' (Stns 2 to 4) and 'other' stations (Stns 5 to 12). Observation from Stn 4 on 22 May has been included. Regressions are: $T$ longicornis, shelf-stations: $Y=-1.9+$ $21.5 X\left(r^{2}=0.99\right)$, other stations: $Y=-0.8+7.6 X\left(r^{2}=0.90\right)$; A. clausi, shelf-stations: $Y=10.1+17.1 \times\left(\mathrm{r}^{2}=0.95\right)$, other stations: $Y=16.4+7.1 \times\left(r^{2}=0.67\right)$

pattern was most pronounced for Temora longicornis but Acartia clausi showed the same trend. Specific growth rates of pelagic bacteria showed a nearly inverse pattern, with peak rates (or minimum generation times) at the strongly stratified stations in the central part of the Skagerrak, where the plankton flora in surface waters was characterized by small forms that primarily utilized $\mathrm{NH}_{4}^{+}$. These data suggest that a 'microbial loop' type of food web was evolving in the central parts, and a more 'classical' type of food web developed along the margin of the Skagerrak. 

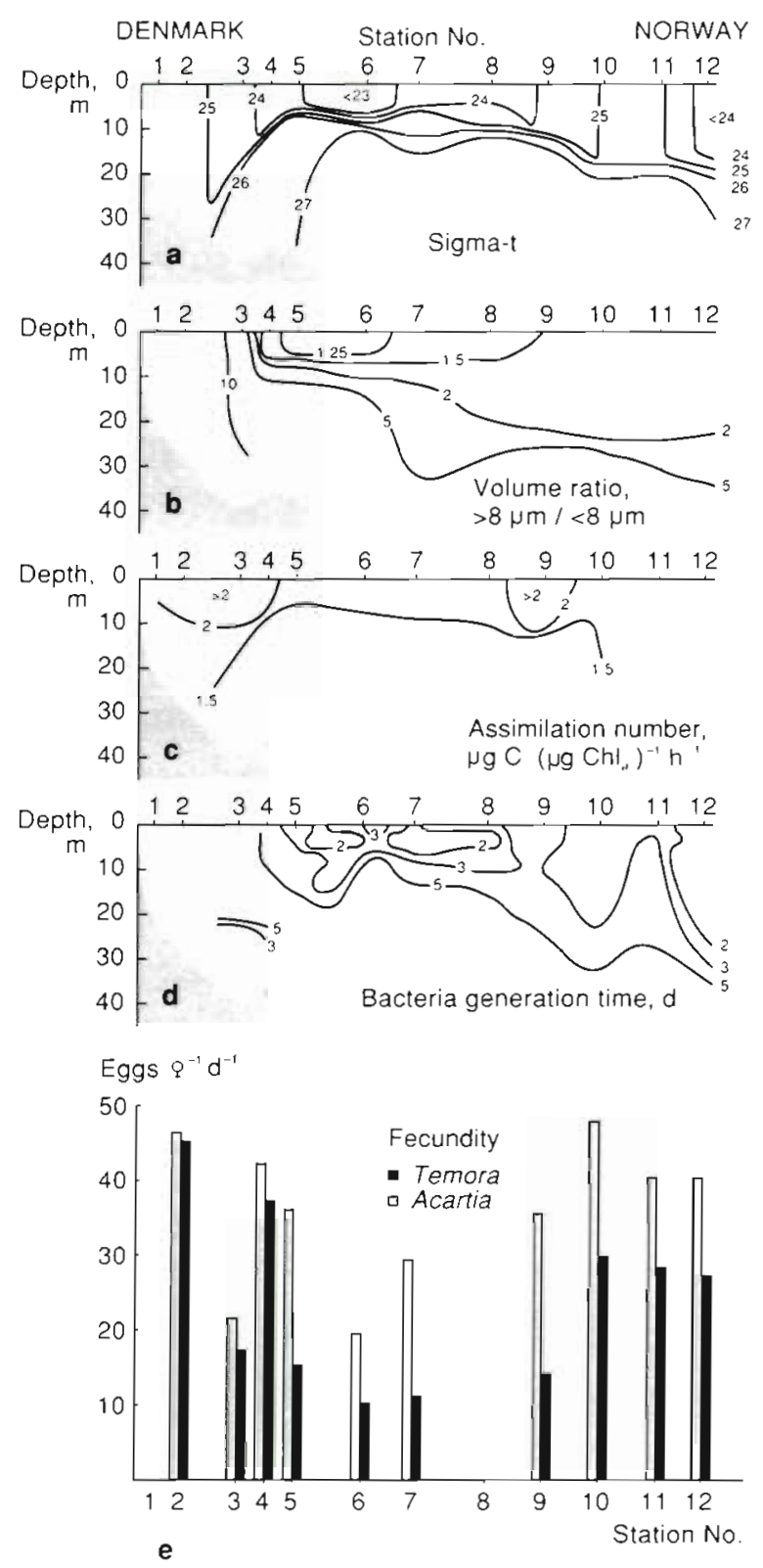

Fig. 9. Vertical distributions of (a) water density, (b) volume ratio of large to small particles ( $>8 \mu \mathrm{m}$ and $<8 \mu \mathrm{m}$, respectively, measured by Coulter Counter), (c) phytoplankton assimilation number and (d) bacterial generation time along the transect. Dots show sampling depths. Lower panel (e) shows egg production rates of the copepods Temora longicornis and Acartia clausi

\section{DISCUSSION}

\section{Size-distribution of phytoplankton}

The variable size-distribution of phytoplankton cells along the transect fits the expectation of dominance of large and/or chain-forming diatoms in turbulent water or areas with a deep mixed layer, and small flagellates in stratified water. Small cell size is a competitive advantage in a nutrient-poor environment (e.g. Fenchel 1987, Jackson 1987), and small cells may remain suspended even in a non-turbulent environment. Turbulence, on the other hand, may be a prerequisite for large diatoms to remain suspended. Furthermore, vertical mixing is often associated with nutrient enrichment of the photic layer and may, therefore, decrease the competitive pressure for small size. In the present case, however, this variability in size-composition accompanying variations in the vertical structure of the water column was apparently not caused solely by variable nutrient availability. For example, the entirely mixed water column close to the Danish coast, dominated by large diatoms, exhibited nitrogen and in particular phosphorus concentrations below or near the level for chemical detection. Even though the flux of nutrients is not necessarily mirrored by variations in nutrient concentration (unfortunately there are no ${ }^{15} \mathrm{~N}$ uptake experiments from the southernmost stations), it seems more likely that the dominance of large diatoms here was rather related to turbulence per se - that is, by keeping heavy diatoms in suspension and/or by creating a fluctuating light environment to which diatoms are adapted (Richardson et al. 1983). Harris et al. (1983) likewise explained the empirical relationship between average phytoplankton size and mixed layer dynamics in freshwater Lake Ontario (Canada) as a consequence of the variable light regime and an observed positive correlation between photosynthetic quantum efficiency and cell size.

At the central stratified stations ammonium was the primary nitrogen source, small flagellates dominated, and, as judged from the increase in specific uptake rate (ca 2.5-fold) in response to high ${ }^{15} \mathrm{NH}_{4}^{+}$administration, cell growth was probably limited by nitrogen availability (Glibert 1988). Further north, where the vertical stability decreased, nitrate supported almost half of the primary production, nutrient concentrations (both $\mathrm{N}$ and P) were generally higher, and the dominating chain-forming algae showed only slight (Stn 9) or no (Stns 10 and 12) signs of nitrogen limitation. Thus, a variety of mechanisms related to vertical physical processes may potentially be involved in determining the observed size-distribution of phytoplankters along the transect.

Biomass, production and growth rate of bacteria and copepods

The size-distribution of phytoplankton may influence the structure of the pelagic food chain by altering the DOM flux rate and the composition of grazers. Here we consider the specific activities of bacteria and copepods 
as representatives of the 2 'alternative' pathways for primary production. Most previous studies of pelagic food web structure in relation to hydrodynamic processes have rather considered biomasses and, to some extent, absolute praduction rates (e.g. Holligan et al. 1984, Le Févre \& Frontier 1988). However, while specific growth rates depend on the currently prevailing chemical, physical and biological conditions, absolute production rates also depend on the biomass of the considered organisms themselves that, in turn, may be the result of biotic and/or physical processes in the past. This is perhaps particularly relevant for copepods, since they have long generation times in comparison to their algal food, and advection, predation etc. may, therefore, obscure potential copepod-phytoplankton distributional relationships (see Kiørboe et al. 1988b). This may, however, also be the case for pelagic bacteria; for example classical Lotka-Volterra predatorprey oscillations have been demonstrated for flagellate-bacteria in natural systems (Fenchel 1982, cf. also Andersen \& Fenchel 1985). Also, even though bacterial production and growth most often seem to be resourcelimited (cf. the frequently observed correlation to measures of phytoplankton biomass or production), specific growth rates generally appear to be densityindependent (cf. Fuhrman et al. 1980, Hanson et al. 1986).

In open oceans bacterial production is ultimately limited by phytoplankton production (as are all heterotrophic processes), and several examples of correlations between bacterial production and phytoplankton biomass or production have been reported (e.g. Fuhrman et al. 1980, Cole et al. 1988). However, such correlations may depend on the scale of the observations (cf. McManus \& Peterson 1988). Thus, Ducklow (1984) observed that bacteria and chlorophyll were uncorrelated on a scale comprising the interior of an ocean warm-core ring but were significantly correlated on larger spatial scales. These observations suggest that small-scale spatial (or temporal) distribution of production rates and in particular biomasses may be difficult to interpret in a dynamic environment such as the Skagerrak, whereas specific growth rates, where historical 'noise' has been removed, may show interpretable relations to relevant environmental variables (e.g. Figs. 7 and 8 ).

The relationship between particle surface area and bacterial generation time (Fig. 7) is surprisingly good in light of the crude assumptions involved in calculating surface area: not all particles counted by the Coulter Counter are living organisms, and few of them can be considered spherical. Also, only particles larger than $2.5 \mu \mathrm{m}$ ESD have been considered, while in fact a considerable surface area may be due to smaller phytoplankters. In spite of this the observa- tion is in good accordance with the expectation of surface-area limited exudation rate of DOM (Bjornsen 1988) and suggests that phytoplankton (and small zooflagellates) are the main source of DOM (except at $\operatorname{Stn} 12$ ).

The ratio of bacterial net production to primary production peaked at central, stratified Stn 5, and reached a low at Stns 8 to 11 concurrent with a deepening of the upper mixed layer. However, both bacterial biomass and production appeared to reach values similar to or exceeding phytoplankton biomass and production, respectively. Although secondary production can easily exceed primary production (Strayer 1988) (while heterotrophic respiration cannot), the ratios reported here seem unreasonably high (Fig. 6). Most likely our estimates of bacterial biovolume $\left(\overline{\mathrm{X}}=0.20 \mu \mathrm{m}^{3} \mathrm{cell}^{-1}\right)$ are by far too high, presumably owing to the coarse units $(0.45 \mu \mathrm{m})$ in our microscope eyepiece micrometer. Using a lower and perhaps more likely estimate of 0.06 $\mu \mathrm{m}^{3}$ cell $^{-1}$ (Lee \& Fuhrman 1987) takes the ratios of bacterial to primary production to within a more reasonable range $(0.03$ to 0.4$)$. The estimates of bacterial generation time is independent of the estimate of bacterial volume or biomass.

In Temora longicornis and to some extent also Acartia clausi variations in fecundity followed variations in the vertical structure of the water column along the transect (Fig. 9). The present data, thus, confirm several previous reports of enhanced copepod activity (feeding, growth, fecundity) at spatio-temporal discontinuities in water column structure with an intermediate depth of the upper mixed layer (i.e. not too deep to prevent primary production and sufficiently deep and turbulent to allow growth of large phytoplankton). Such oceanographic discontinuities where enhanced copepod activity has been documented include tidal fronts (Kiørboe \& Johansen 1986, Kiørboe et al. 1988a), coastal upwelling (Hanson et al. 1986, Peterson \& Bellantoni 1987), storm events (Cowles et al. 1987, Kiørboe et al. 1988a,b) and vernal stratification of the water column (e.g. Williams \& Lindley 1980, Krause \& Thrams 1983).

Although copepod activity may be related both to turbulence per se (e.g. Rothschild \& Osborn 1988, Alcarez et al. in press) and to nutritional quality and growth rate of the phytoplankton (e.g. Cowles et al. 1988, Kiørboe 1989) (cf. Fig. 9), most of the variation in copepod fecundity along the Skagerrak transect is accounted for by variation in the concentration of large phytoplankton (Fig. 8). A similar relationship between water column stratification, phytoplankton cell size and copepod fecundity was demonstrated in several ecosystems by Peterson \& Bellantoni (1987), and is probably the most likely general explanation of enhanced copepod activity at oceanographic interfaces. 


\section{Hydrodynamical processes and pelagic food web structure}

The pattern that seems to have prevailed in the Skagerrak at the time of this cruise was that a microbial type of food web evolved in the central, strongly stratified part of the Skagerrak (Stns 5 to 8), while a shorter 'classical' type of grazing food chain appeared to dominate along the periphery (Stns 1 to 4 and 9 to 11), although there were no sharp boundaries between the different communities. The pattern is most clearly illustrated by instantaneous specific growth rates (Fig. 9), where historical 'noise' has been removed. In support of our working hypothesis the variation in the structure of the food chain seems to be related to variations in the size-distribution of phytoplankton that in turn primarily depend on vertical physical processes.

This idea is also supported by some observations reported in the literature. Thus, Andersen (1988) found in various parts of the Bering Sea that microorganisms

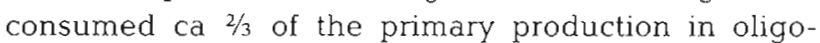
trophic areas characterized by pico- and nanoplankton but only $1 / 20$ in rich, frontal, diatom-dominated areas. A similar difference in the significance of microorganisms was found for a spring (mixed water column, diatoms) and a summer (stratified, nanoflagellates) situation in the North Sea by Nielsen \& Richardson (1989). Hanson et al. (1986) described an upwelling event at the Spanish coast that caused an intense, short-lived diatom bloom. Mesozooplankton grazing peaked concurrent with the upwelling event and accounted for all primary production at its height, whereas the significance of pelagic bacteria increased in the stratified, oligotrophic situation that developed subsequently. The variation in food web structure across this temporal discontinuity in water column structure shows clear resemblance to the spatial variation described in this study

Le Févre \& Frontier (1988) discussed the relation between physical processes and the structure of the pelagic food web, and considered the time-scale of the physical forcing as the main determinant of pelagic food web structure at oceanographic discontinuities. They considered 2 examples, a tidal front, where the fertilizing mixing processes occur in a $14 \mathrm{~d}$ cycle (neapspring tide), and the Celtic Sea shelf-break area, where the fertilizing period is that of the $M_{2}$ tide (i.e. $12 \mathrm{~h}$ ) Based on observed distributions of biomasses they concluded that in the latter case enhanced productivity was in the form of a classical herbivore food chain, while in the former case, primary production was consumed by microorganisms, since herbivarous copepods cannot adapt to short-lived, fortnightly phytoplankton blooms. However, even though advection may prevent accumulation of mesozooplankton with long generation times, both growth and production of copepods may very well be elevated at tidal fronts (e.g. Kiorboe \& Johansen 1986, Kiørboe et al. 1988a). Also, turbulencegenerated diatom blooms that are not grazed by mesozooplankton are more likely to sediment to the bottom than to pass through a microbial food chain (cf. Smetacek 1980, Peinert et al, 1982, Andersen 1988).

The relationship between food web structure and physical processes suggested here may be more evident on oceanwide or seasonal scales. While the food web structure in permanently stratified ocean gyres appear to be of the microbial loop type, upwelling systems may support a shorter, classical food web and a large fishery (e.g. Ryther 1969, Cushing 1989). We suggest that such relations recur on finer temporal and horizontal scales. The perspective in terms of fisheries may be that it is the spatial and temporal frequency of vertical mixing events, at which a large proportion of the primary production is potentially channelled to higher trophic levels, rather than total primary production, that determines the magnitude of the fisheries in a particular sea area.

Acknowledgement. Thanks are due to Prof. Fl. Bo Pedersen for valuable suggestions to the interpretation of the physical data.

\section{LITERATURE CITED}

Alcaraz, M., Estrada, M., Marrase, C. (in press). Interaction between turbulence and zooplankton in laboratory microcosms. In: Klekowski, R. Z., Styczynska-Jurewicz, E., Falkowski, L. (eds.) Proc. 21st Eur. mar. Biol. Symp. Ossolineum, Gdansk

Andersen, P. (1988). The quantitative importance of the microbial loop' in the marine pelagic: a case study from the North Bering/Chukchi Seas. Arch. Hydrobiol. (Beih. Ergeb. Limnol.) 31, 243-251

Andersen, P., Fenchel, T (1985). Bacterivory by microheterotrophic flagellates in seawater samples. Limnol. Oceanogr. 30: 198-202

Azam, F. Fenchel, T., Field, J. G., Gray, J. S., Meyer-Reil. L. A., Thingstad, F. (1983). Mar Ecol. Prog. Ser. 10: 257-263

Baltic Marine Enrivonment Protection Commission - Helsinki Commission (1988). Guidelines for the Baltic Monitoring Programme for the third stage; Part D. Biological determinants. Baltic Sea Environmental Proceedings No. 27D $161 \mathrm{pp}$.

Berggreen, U., Hansen, B., Kiorboe, T (1988). Food size spectra ingestion and growth of the copepod Acartia tonsa: implications for the determination of copepod production Mar Biol. 99: 341-352

Bjørnsen, P. K. (1986). Automatic determinations of bacterioplankton biomass by means of image analysis. Appl. environ. Microbiol. 51: 1099-1104

Bjornsen, P. K. (1988). Phytoplankton release of organic matter: why do healthy cells do it? Limnol. Oceanogr. 33: $151-154$

Cole, J. J., Findlay, S., Pãce, M. L. (1988). Bacterial production in fresh and saltwater ecosystem: a cross-system overview. Mar Ecol. Prog. Ser. 43: 1-10

Cowles, T J., Olsen, R. J., Chrisholm, S. W (1988). Food 
selection by copepods: discrimination on the basis of food quality. Mar. Biol. 100: 41-49

Cowles, T J., Roman, M. R., Ganzens, A. L., Copley, N. J. (1987). Short-term changes in the biology of a warm-core ring: zooplankton biomass and grazing. Limnol. Oceanogr. 32: $653-664$

Cushing, D. H. (1989). A difference in structure between ecosystems in strongly stratified waters and those that are only weakly stratified. J. Plankton Res. 11: 1-13

Ducklow, H. W. (1984). Geographical ecology of marine bacteria: physical and biological variability at the mesoscale. In: Klug, M. J., Reddy, C. A. (eds.) Current perspectives in microbiology. American Society for Microbiology, Washington, p. 22-31

Dugdale, R. C., Goering, J. J. (1967). Uptake of new and regenerated forms of nitrogen in primary productivity. Limnol. Oceanogr. 12: 196-206

Fenchel, T (1982). Ecology of heterotrophic microflagellates. IV Quantitative occurrence and importance as bacterial consumers. Mar. Ecol. Prog. Ser. 9: 35-42

Fenchel, T (1987). Ecology - potentials and limitations. In: Kinne, O. (ed.) Excellence in ecology 1. Ecology Institute, Oldendorf/Luhe, FRG

Fogg, G. E. (1986). Picoplankton. Proc. R. Soc. Lond. B 228: 1-30

Frost, B. W. (1972). Effect of size and concentration of food particles on the feeding behaviour of the marine planktonic copepod Calanus finmarchicus. Limnol. Oceanogr. 17: $805-815$

Fuhrman, J. A., Ammerman, J. W., Azam, F. (1980). Bacterioplankton in the coastal euphotic zone: distribution, activity and possible relationships with phytoplankton. Mar Biol. 60: 201-207

Fuhrman, J. A., Azam, F. (1980). Thymidine incorporation as a measure of heterotrophic bacterioplankton production in marine surface waters: evaluation and field results. Mar. Biol. 66: 109-120

Furuya, K., Marumo, R. (1983). Size distribution of phytoplankton in the western Pacific Ocean and adjacent waters in summer Bull. Plankton Soc. Japan 30: 21-32

Gargas, E., Nielsen, C. S., Lonholdt, J. (1976). An incubator method for estimating the actual daily plankton algae primary production. Water Res. 10: 853-860

Glibert, T M. (1988). Primary productivity and pelagic nitrogen cycling. In: Blackburn, T. H., Sørensen, J. (eds.) Nitrogen cycling in coastal marine environments. John Wiley \& Sons Ltd, Chichester, p. 2-31

Grasshoff, K. (1976). Methods of seawater analysis. Verlag Chemie, Weinheim

Hanson, R. B., Alvarez-Ossorio, M. T., Cal, R., Campos, M. J., Roman, M. R., Santiago, G., Varela, M., Yoder, J. A. (1986). Plankton response following a spring upwelling event in Ria de Arosa, Spain. Mar. Ecol. Prog. Ser. 32: 101-113

Harris, G. P., Ganf, G. G., Thomas, D. P. (1987). Productivity, growth rates and cell size distributions of phytoplankton in the SW Tasman Sea: implications for carbon metabolism in the photic zone. J. Plankton Res. 9: 1003-1030

Harris, G. P., Piccinin, B. B., Ryn, J. van (1983). Physical variability and phytoplankton communities: $V$ Cell size niche diversification and the role of competition. A.rch Hydrobiol. 98: 215-239

Hitchcock, G. L., Langdon, C., Smayda, T J. (1987). Shortterm changes in the biology of a Gulf stream warm core ring: phytoplankton biomass and productivity. Limnol. Oceanogr. 32: 919-928

Hobbie, J. E., Daley, R. J., Japser, S. (1977). Use of Nucleopore filters for counting bacteria by fluorescence microscopy Appl. environ. Microbiol. 33: 1225-1228
Holligan, P. M., Harris, R. P., Newell, R. C., Harbour, D. S., Head, R. W., Linley, E. A. S., Lucas, M. I., Tranter, P. R. G., Weekley, C. M. (1984). The vertical distribution and partitioning of organ carbon in mixed, frontal and stratified waters in the English Channel. Mar. Ecol. Prog. Ser. 14: $111-127$

Hundahl, H., Holck, J. (1980). A new in situ fluorometer for detection of Rhodamine B and chlorophyll. Rep. No. 42, Inst. Physical Oceanogr., Univ. Copenhagen, p. 145-154

Jackson, G. A. (1987). Physical and chemical properties of aquatic environments. In: Fletcher, M., Cray, T R. G., Jones, J. G. (eds.) Ecology of microbial communities. Cambridge University Press, Cambridge, p. 213-233

Jespersen, A.-M. Christoffersen, K. (1987). Measurements of chlorophyll a from phytoplankton using ethanol as extraction solvent. Arch. Hydrobiol. 109: 445-454

Joiris, C., Billen, G., Lancelot, C., Daro, M. H., Mommaerts, J. P., Bertels, A., Bassicart, M., Nijs, J. (1982). A budget of carbon cycling in the Belgian coast: relative roles of zooplankton, bacterioplankton and benthos in the utilization of primary production. Neth. J. Sea Res. 16: 260-275

Kiorboe, T (1989). Phytoplankton growth rate and nitrogen content: implications for feeding and fecundity in a herbivorous copepod. Mar Ecol. Prog. Ser. 55: 229-234

Kiørboe, T., Johansen, K. (1986). Studies of a larval herring (Clupea harengus L.) patch in the Buchan area. IV. Zooplankton distribution and productivity in relation to hydrodynamic features. Dana 6: 37-51

Kiørboe, T., Munk, P., Richardson, K., Christensen, V., Paulsen, H. (1988a). Plankton dynamics and herring larval growth, drift and survival in a frontal area. Mar. Ecol. Prog. Ser. 44: 205-219

Kiørboe, T., Møhlenberg, F., Riisgård, H. U. (1985). In situ feeding rates of planktonic copepods: a comparison of four methods. J. exp. mar. Biol. Ecol. 88: 67-81

Kiorboe, T., Møhlenberg, F., Tiselius, P. (1988b). Propagation in marine planktonic copepods: production and mortality of eggs. Hydrobiologia 167/168: 219-225

Krause, M., Thrams, J. (1983). Zooplankton dynamics during FLEX 76. In: Sündermann, J, Lenz, W (eds.) North Sea dynamics. Springer-Verlag, Berlin, p. 632-661

Kristiansen, S., Paasche, E. (1982). Preparation of ${ }^{15} \mathrm{~N}$-labelled phytoplankton samples for optical emission spectrometry Limnol. Oceanogr. 27: 373-375

Le Févre, J., Frontier, S. (1988). Influence of temporal characteristics of physical phenomena on plankton dynamics, as shown by north-west European marine ecosystems. In: Rothschild, B. J. (ed.) Toward a theory on biology-physical interactions in the world ocean. Kluwer Academic Publishers, Dordrecht, p. 245-272

Lee, S., Fuhrman, J. A. (1987). Relationships between biovolume and biomass of naturally derived marine plankton. Appl. environ. Microbiol. 53: 1298-1303

Legendre, L. (1981). Hydrodynamic control of marine phytoplankton production: the paradox of stability. In: Nihoul J. C. J. (ed.) Ecohydrodynamics. Proc. 12th int. Liége Colloquium on ocean hydrodynamics. Elsevier, Amsterdam, p. 191-207

Malone, T. C. (1980). Algal size. In: Morris, I. (ed.) The physiological ecology of phytoplankton. Blackwell Scientific Publications, Oxford, p. 433-463

McManus, G. B., Peterson, W. T (1988). Bacterioplankton production in the nearshore zone during upwelling off central Chile. Mar. Ecol. Prog. Ser. 43: 11-17

Nielsen, T. G. Richardson, K. (1989). Food chain structure of the North Sea plankton communities: seasonal variations of the role of the microbial loop. Mar. Ecol. Prog. Ser 56: 75-87 
Olsen, V., Lundgren, B. (1984). A compact eight-channel continuous flow analyzer for shipboard use. Comm. Meet. Int Counc. Explor Sea C. M.-ICES/C: 19

Paasche, E. (1988). Pelagic primary production in nearshore waters. In: Blackburn, I H., Sorensen, J. (eds.) Nitrogen cycling in coastal marine environments. John Wiley \& Sons, Chichester, p. 33-57

Peinert, R., Saure, A., Stegmann, P., Stienen, C., Haardt, H., Smetacek, V. (1982). Dynamics of primary production in a coastal ecosystem. Neth. J. Sea Res. 16: 276-289

Peterson, W. T., Bellantoni, D. C. (1987). Relationship between water-column stratification, phytoplankton cell size and copepod fecundity in Long Island Sound and off the central Chile. S. Afr. J. mar. Sci. 5: 411-421

Pingree, R. D., Holligan, P. M. Mardell, G. T., Harris, R. P. (1982). Vertical distribution of plankton in the Skagerrak in relation to doming of the seasonal thermocline. Cont. Shelf Res. 1: 209-219

Richardson, K., Beardall, J., Raven, J. A. (1983). Adaptation of unicellular algae to irradiance: an analysis of strategies. New Phytol. 93: 157-191

Riemann, B., Bjornsen, P. K., Newel, S., Fallon, R. (1987). Calculation of cell production of coastal marine bacteria based on measured incorporation of $\left({ }^{3} \mathrm{H}\right)$ thymidine. Limnol. Oceanogr. 32: 471-476

This article was submitted to the editor
Rothschild, B. J., Osborn, T R. (1988). Small-scale turbulence and plankton contact rates. J. Plankton Res. 10: 465-474

Ryther, J. H. (1969). Photosynthesis and fish production in the sea. Science 166: 72-76

Smetacek, V. (1980). Animal cycle of sedimentation in relation to plankton ecology in western Kiel Bight. Ophelia, Suppl $165-76$

Strayer, D. (1988). On the limits of secondary production Limnol. Oceanogr. 33: 1217-1220

Såby Johansen, H. (1984). Improved optical analysis of traces depleted or slightly enriched in ${ }^{15} \mathrm{~N}$. Int. J. appl. Radiat. Isot. 35: 1039-1043

Tanaka, T., Sano, M., Okunuma, J (1988). Changes in size composition of summer primary producers in euphotic Mikawa Bay, Japan. Bull. Plankton Soc. Japan 35: 21-34

Tranter, D. J. (ed.) (1968). Zooplankton sampling. Monographs on oceanographic methodology. UNESCO, Paris, $174 \mathrm{pp}$

Watson, S. W., Noritsley, T. J., Quinby, H. L., Valois, F. W. (1977). Determination of bacterial number and biomass in the marine environment. Appl. environ. Microbiol. 33 940-946

Williams, R., Lindley, J. A. (1980). Plankton of the Fladen Ground during FLEX 76. III. Vertical distribution, population dynamics and production of Calanus finmarchicus (Crustacea: Copepoda). Mar Biol. 60: 47-56

Manuscript first received: February 27, 1989

Revised version accepted: September 6, 1989 